\title{
Which Love in Law? Zenon Bańkowski and the Meaning of Love
}

\author{
Renata Grossi
}

\begin{abstract}
Zenon Bańkowski has challenged the popular view that law and love are opposites. Instead he has argued that they are 'entangled', 'necessary', and even 'dependent' on each other. Together they form the 'unity' that is required for us to live a lawful life. He argues that to see them as opposites is not only inaccurate, but also constitutes a 'moral and cognitive failure'. If he is right, and we are to see love and law as connected to one another, the question arises of what he means when he talks of love. This inquiry will show that Bańkowski relies on ideas of love that spring from the Classical (eros), the Christian (agape) and the romantic traditions; however I will argue that a conception of love that also fits his argument is friendship love (philia).
\end{abstract}

\section{INTRODUCTION}

What relation with law is demanded by the concept of love? It is a common, if not the most common, perception that law and love are opposites, often represented in a dichotomous relationship where law is exemplified by reason, predictability, rules, regulation and heteronomy and love by emotion, unpredictability, contingency, freedom and autonomy. It is also common to associate law with the market and with capitalism, and love with welfare and altruism. These associations are the source of much misunderstanding about the role of law in society and the choices that citizens face when living lawfully. A better approach, Bańkowski argues, is to see law and love as interdependent, each unable to function without the other. Accepting this argument requires a discussion of what he means by love.

Love has a long and complicated history. It has been considered through various disciplinary lenses (literature, philosophy, theology, anthropology, sociology, politics, psychology, biology, neurology, evolution studies). It has been studied in connection to sex, marriage, gender and sexuality. It has been understood variously as a biological physical sensation, as an evolutionary development, as a psychological phenomenon, as an emotion, and/or, as a literary, cultural and social construct. ${ }^{1}$ It is often

1 For some studies in thinking about emotions see the following; JM Barbalet, Emotion Social Theory and Social Structure: A Macrosociological Approach (Cambridge University Press, 1998); Cheshire Calhoun and Robert Solomon (eds), What is an Emotion? Classical Readings in Philosophical Psychology (Oxford University Press, 1984); Keith Oatley and Jennifer M Jenkins, Understanding Emotions (Blackwell Publishers, 1996); Keith Oatley, Best Laid Schemes: the Psychology of Emotions (Cambridge University Press, 1992); Robert Solomon (ed), Thinking About Emotions: Contemporary Philosophers on Emotions (Oxford 
the case that there is considerable slippage between these different focal points. It is a difficult task therefore to understand what is being analysed in discussions of love. In this article I will consider love predominantly as a philosophical idea and will discuss its development from the classical (eros), to the Christian (agape), to the romantic and to the contemporary.

It is difficult to confine Bańkowski's use of love. At times he appears to be talking of romantic love, his argument however, also relies on the ideas of love that belong to the classical and to the Christian traditions. However, I will argue that if love is to fulfil the functions Bańkowski wants it to, then we should also consider friendship love (philia).

\section{Bańkowski and the Dependence of LaW and Love}

Bańkowski argues that to see law and love as opposites, is to set up a good versus bad situation, an illusion of a simple divide requiring a simple choice to be made in life concerning how we live a lawful life. To see law and love as opposites creates the idea that one must choose between living a life either in law or out of law. This is impossible, unnecessary and wrong - it represents a 'moral and cognitive failure'. ${ }^{2}$ It is false because we can't make a choice of living either in or out of law - living completely in law is problematic as it is rigid, and makes us scared of contingency. But living without law is equally problematic as it leads to chaos and nihilism. Rules are required to regulate need and conflict. Similarly, love needs to be mediated through law because love's discretion and arbitrariness makes it a potentially dangerous and powerful force. ${ }^{3}$

To illustrate how law and love should operate together, Bańkowski uses the analogy of marriage and love. Like law and love, marriage and love are often seen as opposites. Marriage is depicted as heteronomous, predictable routine while love is spontaneous, creative and autonomous. ${ }^{4}$ But Bańkowski argues for a different relationship between them; not as opposites, not as separate, but as a unity - a 'differentiated unity', ${ }^{5}$ together but still separate. A good analogy he argues is the relationship between love and marriage where we can see love as the expression of autonomy

University Press, 2004); Peter A French and Howard K Wettstein (eds), The Philosophy of Emotion, Midwest Studies in Philosophy XXII (University of Notre Dame, 1999).

2 Zenon Bańkowski, Living Lawfully: Love in Law and Law in Love (Kluwer Academic Publishers, 2001) 41.

3 Ibid, 142.

4 Bańkowski relies on Luhmann for this point. Luhmann claims that Love is spontaneous, in the present, uncoupled from external relations, contingent and a matter of fate, not interested in the future, not bound by duty or obligation, consumes everything, thematises everything. Marriage, on the other hand, is interested in the future or the eternal, as something that reduces spontaneity, calms passion, routinises love, stabilises love. Niklas Luhmann, Love As Passion: The Codification of Passion (Jeremy Gaines and Doris Jones trans, Stanford University Press, 1982).

Bańkowski, above n 2, 211. 
within the heteronomous relationship of marriage. He claims that in this formulation we have the full realisation of the relationship. 'Heteronomy and autonomy are yoked together' ${ }^{6}$ This is the same relationship that we strive for between law and love.

But this view is more than just aspirational. The relationship between law and love is in reality closer to this model and further away from the binary outlined earlier. Law and love are necessary to one another, they criss-cross each other, and at times become entangled together. To illustrate this argument Bańkowski consistently uses two examples: the operation of an automated teller machine illustrates $w h y$ both are necessary, and the relationship between a host and her guest illustrates how both are necessary.

An Automated Teller Machine (ATM) lacks the human element, one cannot approach it and ask it to consider the individual circumstances of the person before it. The machine needs to function predictably, in a lawlike manner. To do this it must forget the individual. It must remove love. 'Law in its universalist form, takes the magic away from the social world by producing predictability and rationality. This is what the computer teller does.' ${ }^{7}$ Law should operate in a machine-like way, but this can only be so up to a point. Law must know when to behave in a creative individual way, "the computer teller must know when the magic has to come back. When it is necessary to stop the "computer" merely repeating itself. When we should treat something as problematic or hard'. ${ }^{8}$

To achieve this, Bańkowski tells us that the ideal is to operate in the middle of law and love. In a space where 'seemingly opposed principles are held in coherent tension'. ${ }^{9}$ This space is not fixed, it is always being remade and it is a 'tense', 'risky' and 'precarious' place because it allows for contingency - we never know where it may lead to. ${ }^{10}$

The example of the host and guest relationship illustrates the way in which a spontaneous act of love (inviting one to stay) gives rise to rules/ laws about how one should behave towards a guest. Once the relationship is established the divide between love and law is no longer clearly distinguishable. He says, 'mysterious explosions of love, [carry with them] the bonds of rules and rationality. The loving act [is] part of the lawful act. And it is the intertwining of the two that make the act appropriate - not one or the other'. ${ }^{11}$ A good analogy for this is the English Common law of negligence in relation to rescue. There is no duty to rescue a person - you make that decision according to an act of love - but once you do, then there are rules about how to behave in the situation that the law imposes upon you. ${ }^{12}$

$6 \quad$ Zenon Bańkowski, 'Law, Love and Computers' (1996) Edinburgh Law Review 40.

7 Bańkowski, above n 6, 40.

8 Ibid.

9 Bańkowski, above n 2, 113.

10 Ibid, 114.

11 Ibid, 101.

12 Ibid. 
What these examples tell us is that love is needed to make law respond to individual circumstances and to meet individual needs. It functions to reduce the rigidity of rules (legalism). ${ }^{13}$ Love also motivates social acts that are not necessarily required or facilitated by laws, but are nevertheless required, or at least are desirable in society. These are important functions to attribute to love, in fact one might argue that Bańkowski demands too much of love, however even before we get to this, to evaluate the claims one must ask what Bańkowski means when he is talking of love.

\section{The Meanings of Love}

The earliest discussion of love in western culture can be found in Plato's Symposium. ${ }^{14}$ Here Simon May claims we find two lasting ideas of love. ${ }^{15}$ In the speech of Aristophanes we hear that love is a longing to find a part of ourselves, and that when we find it, it constitutes a unification, a merging of both our bodies and our souls which 'heal the human sore'. ${ }^{16}$ From the speech of Socrates delivered as the ideas of Diotima (priestess and expert on love) we learn that love is the quest for the attainment of beauty, wisdom and the good. Love is represented as a ladder that begins with the erotic at the lowest rung and ends with an abstract love at the highest. Love is aroused by the beauty of a person's looks as well as their soul, character and deeds; it begins with sexual attraction but it is more than that; it raises us to higher things (Diotima/Socrates). Love has stages. In the first stage, a young lover will apply himself to the contemplation of physical beauty, moving from one lover to another, realising that beauty is not limited to one type. In the second stage, a lover will become a lover of beauty in a more general sense and will relax his passion for one person as this will be considered beneath him. In the third stage, a lover will come to realise that the soul is more valuable than the body, and he will therefore come to appreciate that beauty on the inside is more valuable than outward signs of beauty. The fourth stage consists of the realisation that the concept of beauty can encompass social and moral beauty. This will lead to a desire to acquire knowledge. The fifth stage is the realisation of absolute and pure beauty. ${ }^{17}$

Cordoner has argued that this conception of love is a very needy one, based on human imperfection, the lack of something in a person that can only be met by another. ${ }^{18}$ It is also questionable whether the idea of

13 Judith Shklar, Legalism (Harvard University Press, 1964). Relying on this text Bańkowski makes a distinction between legality that includes love, and legalism which constitutes a blind obedience to rules: Ibid, 42 .

14 Plato, Symposium (WRM Lamb trans, Loeb Classical Library Harvard University Press, 1975).

15 Simon May, Love a History (Yale University Press, 2011) 40.

16 Plato, above n 14, 141.

17 Ibid, 173-211.

18 Christopher Cordner, 'Two conceptions of love in philosophical thought' (2001) 50(3) Sophia: International Journal of Philosophy and Traditions 315. 
merger embedded in the myth of Aristophanes is compatible with ideas of autonomy that are so valued in contemporary society. ${ }^{19}$

Christianity developed the idea of love as a means to attain goodness even further. Solomon says that Christianity raised the idea of love to divine significance. "The Christian conception of love aimed always "higher", toward not just virtue or happiness but perfection itself. It is with Christianity that love becomes literally "divine" - not just exhilarating but an absolute in itself. ${ }^{20}$

Christianity exalted love to the ultimate ideal it has become by asserting that there is nothing better than to love and be loved. In fact for many Christians their faith hangs upon the two commandments: 'Thou shalt love the Lord thy God with all thy heart, and with all thy soul, and with all thy mind'; 'Thou shalt love thy neighbour as thyself'. ${ }^{21}$

The importance of love is also found in the works of St Paul. In his first letter to the Corinthians, St Paul says that love is greater than all knowledge, wealth, power and even faith, he says:

Love is patient; love is kind; love is not envious or boastful or arrogant or rude ... It bears all things, believes all things, hopes all things, endures all things ... And now faith, hope, and love abide, these three; and the greatest of these is love. ${ }^{22}$

St John the Evangelist preached that love brings us as close as possible to God: 'God is love, and those who abide in love abide in God, and God abides in them'. ${ }^{23}$ St Augustine elevates love even further by making it the measure of our virtue. ${ }^{24}$ Never, Simon May says, had love been so extravagantly considered, in these views we see 'the foundation stone of our deep belief that a life without great love, whether directed at a romantic lover, our children, God, or a stranger in need, is impoverished in a way for which no heroic deeds or original achievements can ever compensate'. ${ }^{25}$

The general features of Christian love, according to Andres Nygren are that it is spontaneous, unmotivated, and unconnected to value and worth. It is not dependent upon an external object or a desire for good. God's love does not need any special motivation; it issues spontaneously through nature, it simply radiates, like the glorious sun or the universe

19 Merger is considered particularly problematic for women. See Marilyn Freedman, 'Romantic Love and Personal Autonomy' in Peter A French and Howard K Wettstein (eds), Midwest Studies in Philosophy, Vol XXII (Wiley, 1998) 162-181.

20 Robert Solomon, About Love Reinventing Romance for Our Times (Little Field Quality Paperbacks, 1994) 57.

21 Matthew $22<$ https://www.biblegateway.com/passage/?search=Matthew\%20 22:35-40\&version $=\mathrm{NIV}>$.

221 Corinthians 13 <https://www.biblegateway.com/passage/?search=1\%20 Corinthians $+13 \&$ version $=\mathrm{NIV}>$.

231 John 4 <https://www.biblegateway.com/passage/?search=1\%20John+4\& version $=\mathrm{NIV}>$.

24 May, above n 15, 87.

25 Ibid, 86. 
at large, giving forth energy for no apparent reason'. ${ }^{26}$ Similarly, agape is not dependent upon value; it is indiscriminate, unconcerned about the prior value of what it chooses to love, 'the worthless, the sinful, the evil may receive God's love as readily as the holy and the upright'. ${ }^{27}$

But love needed to be brought down to earth, and sexual love needed to be given some legitimacy. This was achieved by courtly love, and subsequently by romantic love. Courtly love emerged in the 12 th century among a small section of the predominantly French aristocracy. ${ }^{28}$ Its ideas were proselytised by Troubadours who performed highly stylised poems whose themes were commonly embedded in a story of a poet or knight's love for an aristocratic lady who was inaccessible. The stories often depicted a struggle between love, desire and duty. ${ }^{29}$ Its features were: that the love between men and women is something splendid, and an ideal worth striving for; that it is ennobling for both the lover and the beloved; that sexual love is more than libido or a physical impulse but something ethical and aesthetic; that love has rituals within it but it is not necessarily related to marriage; and finally that love is an intense and passionate relationship that establishes a oneness between the lovers. These ideas were the foundation of contemporary concepts of romantic love. ${ }^{30}$

Like courtly love, romantic love cherishes and idealises the love between men and women. It too ennobles lovers and sees love as ritualistic and spiritual, as a means by which a oneness between lovers is created. It sees sex as both pleasurable and good. However it would be a mistake to see romantic love purely as a restatement of the courtly tradition. Romantic love reflects the many changes that had occurred following the Middle Ages, and can be seen as reflecting a new kind of humanism which embodies ideas of liberty and equality, and importantly, extends those ideas to the whole of society. As Singer put it:

By the nineteenth century every scullery maid could dream of dancing her way into some Prince Charming's heart, and every young aristocrat could yearn for the vampish woman of the streets who would elicit his true virility. ${ }^{31}$

Solomon echoes this by arguing that Romantic love is a 'great levelling device' in society: a force that not only requires equals but is capable of

26 Anders Nygren quoted in Irving Singer, The Nature of Love, Volume 1 (University of Chicago Press, 1966) 275.

27 Ibid.

28 See Andreas Capellanus, The Art of Courtly Love (JJ Parry trans, Frederick Ungar Publishing, 1941) and Irving Singer, The Nature of Love, Volume 1 (University of Chicago Press, 1966).

29 A typical story of courtly love can be told by Tristan and Iseult. Sir Tristan is a knight who is sent by his King to negotiate for the hand of a neighbouring princess and bring her home to him to be his queen. On the return journey they fall in love. The rest of the story is about their affair and how they try to keep their love and fulfil their respective duties to the King: Bérol, Tristan and Iseult a Twelfth Century Poem (Janet H Caulkins and Guy R Mermier trans, $\mathrm{H}$ Champion, 1967).

30 Irving Singer, The Nature of Love, Volume 2 (Chicago University Press, 1984).

31 Irving Singer, The Nature of Love, Volume 3 (Chicago University Press, 1987) 18. 
creating them, and it is for this reason he claims that romantic love 'now finds its greatest popularity in self-consciously egalitarian societies'. ${ }^{32}$ Hendrick and Hendrick claim that primarily love must accord individuals a certain freedom and autonomy, and love must itself be liberated from considerations of economy and politics. ${ }^{33}$ These presuppositions depend upon a modern western industrial society, and thus love becomes connected not only with individual freedom, but also modernity and progress. ${ }^{34}$

Contemporary love has developed many of the features of love that were begun during the romantic period. If love was extended to the masses during that time, the message has now reached saturation point in our culture. Beck and Beck-Gernsheim claim that love is now considered the major existential goal of our times, capable of providing all of us with a sense of worth and a way of being in the world..$^{35}$ Illouz claims that love has become the 'cultural core of modernity', ${ }^{36}$ a supreme value capable of delivering happiness - a 'collective utopia' ${ }^{37}$ Bruckner has described it as the general ideology of the West, ${ }^{38}$ and May, as the 'undeclared religion of the west, 'the ultimate source of meaning and happiness'. ${ }^{39}$ According to these writers the key messages in contemporary society are that love is a selfless, unconditional 'gift' that affirms the loved one, that transforms us to a higher state of being, is eternal, benevolent, harmonious and redeems us from our suffering. ${ }^{40}$ Love gives us a feeling of 'living in high altitude', ${ }^{41}$ it represents a 'Dionysian affirmation of life'. ${ }^{42}$ We seek love because it makes us feel at home, it roots our life, it validates and solidifies our

32 Solomon, above n 20, 45.

33 Susan Hendrick and Clyde Hendrick, Romantic Love (Sage Publications, 1992) 39.

34 The idea that romantic love is radical, liberating and modern has spread beyond western societies. It finds expression for example in challenges to common (mis) perceptions of arranged marriages in India, and in the Red Love context, it is equated with the shattering of capitalism. The revolutionary nature of romantic love is also a theme in communist countries where romantic love is equated with revolutionary ideas such as Marxism. See the concept of Red Love which originated from the novel by the same name by Alexandra Kollontai. Red Love appears to be used to signify the coincidence of romantic love with Marxism, and at least for some implies free love. See Teresa L Ebert, Alexandra Kollontai and Red Love <http://www.solidarity-us.org/node/1724> (accessible on 11 January 2016). For the idea of romantic love in India see Rochona Majumdar, Marriage and Modernity: Family Values in Colonial Bengal (Duke University Press Books, 2009) 7. See also Ratna Kapur, Erotic Justice: Law and the New Politics of Postcolonialism (Glasshouse Press, 2005) 157-158.

35 Ulrich Beck and Elizabeth Beck-Gernsheim, The Normal Chaos of Love (Polity, 1994) 193-194.

36 Eva Illouz, Why Love Hurts: a Sociological Explanation (Polity, 2012) 120.

37 Eva Illouz, Consuming the Romantic Utopia (University of California Press, 1997) 2.

38 Pascal Bruckner, The Paradox of Love (Princeton University Press, 2012).

39 May, above n 15, 1.

40 Ibid, 2.

41 Bruckner, above n 38, 75.

42 Ibid, 218. 
existence, it 'deepens our sense of being', it enables us to 'experience the reality of our life as indestructible', it offers us a promise of 'ontological rootedness'. ${ }^{43}$ We crave this because we are born with an 'intense feeling of vulnerability'. ${ }^{44}$ It achieves this because it is the 'central link - in the long chain of interaction rituals'. ${ }^{45}$ Its prominence is assisted by the fact that it is a common theme in mass culture, especially film and advertising, and has become associated with mass consumption and the ideology of consumerism. ${ }^{46}$

Contemporary love also continues the themes of liberty and freedom. Beck and Beck-Gernsheim assert that love requires individuals who are free, active and accountable agents, ${ }^{47}$ and a context free of any external rules and pressures: love is a blank form whose actual content is a 'subjective and mutual invention'. ${ }^{48}$ It is these features of contemporary love that for Anthony Giddens make it a potential for significant social transformation. Giddens claims that the rise of romantic love today has led to the democratisation of the private sphere. It has given rise to the 'pure relationship' which is a durable emotional tie that can be established according to another person on the basis of the tie itself rather than to anything extrinsic to it. ${ }^{49} \mathrm{He}$ says that the pure relationship is "part of a generic restructuring of intimacy' which can emerge in contexts other than heterosexual marriage.$^{50}$ Essential to the emergence of the "pure relationship' is the emergence of 'plastic sexuality', a sexuality which 'functions as a malleable feature of self, a prime connecting point between body, self-identity and social norms'. ${ }^{51}$ Romantic love has given way to 'confluent love', an ideal of love that gives everyone a chance to become sexually accomplished that is not necessarily heterosexual or monogamous. In the model of the pure relationship and confluent love the relationship holds only while each partner is gaining sufficient benefit from it. Importantly for same-sex love, confluent love differs from romantic love because 'while not necessarily androgynous, and still perhaps structured around difference, [it] presumes a model of the pure relationship in which knowing the traits of the other is central'. ${ }^{52}$ As such, sexuality is only one of the factors to be negotiated as part of the relationship. While Giddens' formulation of love in modern society has been criticised for not reflecting reality, ${ }^{53}$ its importance is in its formulation of a democratic way of understanding

43 May, above n $15,6$.

44 Ibid, 10.

45 Illouz, above n 36, 120.

46 Illouz, above n 37, 28.

47 Beck and Beck-Gernsheim, above n 35.

48 Ibid, 193.

49 Anthony Giddens, The Transformation of Intimacy: Sexuality Love and Eroticism in Modern Societies (Polity Press, 1992) 2.

$50 \quad$ Ibid, 58.

51 Ibid, 15.

52 Ibid, 63.

53 Lynne Jamieson, 'Intimacy Transformed? A Critical Look at the Pure Relationship' (1993) 33 Sociology 477. 
love. For Giddens, 'pure relationship', 'plastic sexuality' and 'confluent love' are all 'part of a generic restructuring of intimacy'54 representing a formulation of love that is more democratic and inclusive than any in the past.

From this discussion we can crudely summarise the features of classical love as a means of finding a part of ourselves, and as a means to attain beauty, wisdom and above all goodness. Love that stems from Christian thought can be described as love for a god which turns into a love for others. It is an unconditional and all-encompassing ideal worth striving for its own sake. Christian love is a rational choice one makes that is connected to living a good life and ensuring a good afterlife. It is not connected to intimacy between two people, nor is it connected to sexual love or sexual satisfaction. Romantic love as begun in the 12 th century with the courtly tradition and continued into the romantic period, took the ideal of love established by Christianity but translated it into a phenomenon that did not need to be mediated through God. As a creature of the Enlightenment, romantic love legitimated humans, their choices, their needs and their desires (sexual and non-sexual). Romantic love is not necessarily connected to goodness and ethical conduct between individuals, but it is considered a good in a wider social and cultural sense because it fits into the ideas of a modern society grounded in principles of humanism, equality of peoples, freedom of choice and autonomy of the individual. These features are amplified in contemporary love. In contemporary society love has become the most important goal for living, firmly embedded in ideas of freedom, autonomy and agency.

\section{Situating Bańkowski's Argument Within the Traditions of Thinking About Love}

In earlier discussion we saw that the function of love in law for Bańkowski is to create an opportunity for the individual circumstance/story to receive a voice and be heard. Love prevents law from becoming blind to individual needs and thus facilitates justice, and it also functions to keep society beyond and above mere rule/law obedience.

Bańkowski's working definition of love is that it is a principle of action that appears to have no reason. He says:

[Love] does not stem from the universalising premises of rationality but rather appears to come from the arbitrary attention that is made to the particular or the concrete circumstance. Arbitrary in the sense that it is a grace and cannot be predicted or captured by rules. In concrete terms we might think of it as the principle of welfare; the principle that has to respond to the particular need of the concrete situation and thus cannot readily be characterised in rule form..$^{55}$

And it is:

54 Giddens, above n 49, 58.

55 Zenon Bańkowski, 'Law, Love and Legality' (2001) 14(2) International Journal for the Semiotics of Law 199. 
spontaneity of autonomy ... of doing something on your own responsibility because it is 'right' and you feel it so. ${ }^{56}$

The key concepts that emerge from this definition are that love is spontaneous, irrational and individual. The definition also reinforces what emerged from his examples discussed earlier, that love is the vehicle that fulfils needs and provides welfare and justice to individual circumstances/ hardships. It is linked to autonomy rather than heteronomy, and it is linked to an internal sense of justice - an internal sense of what is 'right'.

Oche Onazi claims that 'the principle of welfare' is the most concrete and approximate description of love as it is being used by Bańkowski - he refers to Bańkowski's love as his 'ethic of love'. He says that for Bańkowski love is a means of grasping individual pain and suffering and the 'preciousness of human individuality'. ${ }^{57}$ Bursts of love are needed to make our legal and political institutions respond effectively to human suffering and in particular to alleviate human suffering.

Love as an ethic, to achieve goodness, is also suggested as a reading of Bańkowski's love by Francisco Saffie. ${ }^{58}$ Saffie says that Bańkowski's idea of uniting law and love is really about uniting law with ethics. Or even, if we read law as politics, it is about uniting politics and ethics. These ideas of love bring us close to an understanding of it that is closely related to human rights, to justice and to morality. But using love is different because Onazi says rights do not provide an understanding of the suffering of individuals, they are a response to it. Only love can do that ${ }^{59}$ For Bańkowski and Onazi, what love achieves over the discourse of rights is an ability to 'feel' the conditions that in turn motivates the law to act. This is what Bańkowski means by it being something you feel to be right. Love allows us to feel what the law must do, and therefore it is stronger than an intellectual rational discourse of rights and justice.

If Onazi and Saffie are right about Bańkowski then his use of love is connected to the classical idea that love is a means by which we connect to, and attain goodness. But it is also connected to Christian love, to love one's neighbour in the way we love God creates a general, indiscriminate and universal love among all human beings and this love is very much connected to the idea that law needs to respond to human suffering and to embody morality and justice in order to be law. ${ }^{60}$

But what of romantic love? While romantic love does not on the face of it have a connection with human welfare, in fact it can be connected to it via its embodiment of agency, freedom and equality. Romantic love

\section{$56 \quad$ Ibid, 201.}

57 Onazi Oche, 'What's Love got to do with Development?' in Maksymilian Del Mar and Claudio Michelon (eds), The Anxiety of the Jurist - Legality, Exchange and Judgement (Ashgate, 2013) 231.

58 Francisco Saffie 'Fulfilling the Law by Breaking it? Formalism within Legality' in Del Mar and Michelon, ibid, 156-170.

59 Oche, above n 57, 231.

60 The connection of this with natural law theory and therefore Christianity is obvious. 
tells us that everyone, regardless of any of their biographical features, is worthy of giving and receiving love by another human being, and above all that love is a worthy goal and state to be in, as worthy, if not more worthy, than other pursuits (wealth, success, fame and even goodness).

One cannot ignore the romantic love elements that are present in Bańkowski's view. Romantic love is evident when Bańkowski talks of love as a dangerous and powerful force that requires us to be strong in order to approach it or it will destroy us, when he describes love as arbitrary and potentially dangerous, when he talks of love not being able to be captured by rules, as something that constitutes an 'eruption of our souls', as 'magic', and when he is talking of love as embodying autonomy and individual desires, needs and wants. These ideas of love all belong to the radical and subversive romantic and contemporary love discussed above. How then can we reconcile these different traditions of love being reflected in Bańkowski's ideas?

Onazi claims that Bańkowski's use of love belongs to the same tradition that is present in the philosophies of Simone Weil and Raimond Gaita. Simone Weil saw love as a means by which human beings recognise the existence of each other, she in fact describes it as 'the organ of existence'. ${ }^{61}$ Love allows us to feel for others, to share in their suffering as much as in their happiness. She says 'among human beings, only the existence of those we love is fully recognized. Belief in the existence of other human beings as such is love'. ${ }^{62}$ But for Weil, love is closely connected to God. It is God's love for humans that allows us to love each other, and when we love each other we are imitating God.

Raimond Gaita adds to this idea by arguing that love is the conduit through which we come to understand the sacredness of every individual's rights and dignity. He says that:

were it not for the many ways human beings genuinely love one another from sexual love to the impartial love of saints - I do not believe we would have a sense of the sacredness of individuals, or of their inalienable rights or dignity. ${ }^{63}$

Gaita argues that in all its forms, love's primary function is to give us a sense of the 'other' as something to value. Gaita differs from Weil because he disconnects the task from God and includes romantic love by including sexual love.

But how compatible is romantic love with law? On the face of it, if we take the primary function that love is to fulfil in law as argued by Bańkowski, then it is incapable of it because romantic love, as outlined in the discussion above, is ultimately about individual satisfaction, and is selective, preferential and exclusive. It does not really have at its heart

61 George A Panichas (ed), The Simone Weil Reader (David McKay co, 1981) 359.

62 Ibid.

63 Raimond Gaita, A Common Humanity Thinking About Love and Truth and Justice (Text Publishing, 1999) 5. 
any sense of the communal or even any sense of the welfare of others. Some of the feminist critiques of love are telling here. ${ }^{64}$

But romantic love according to Gaita does give us the idea that one can love outside of established social boundaries and conventions. This idea leads to a valuing of all human beings. Gaita says that, "the readiness of lovers to disregard prudence, to love and to suffer for it despite status, class, race, nationality and moral merit, conditions and awakens in us a sense of the mystery and preciousness of human beings'.$^{65}$ In other words, what romantic love does is universalise the worthiness of human beings. The universalising of love, as we saw, is also present in Christianity, but romantic love removed the condition that it must be mediated through our love of God.

This discussion would suggest that Bańkowski's argument relies on all three major conceptions of love: the classical, the Christian and the romantic (including the contemporary); that all three sustain the idea that law is and should be connected to meeting individual needs and welfare for the sake of valuing humanity above rules and systems. And yet to embrace this conclusion one must also overcome some significant sticking points. To what extent can we ignore the fact that Christianity's ideas of love are in the end all dependent on a strict belief system that is rejected by many in modern and post-modern society? Similarly, to what extent can we ignore the idea that romantic love subordinates all to personal individual satisfaction and is, as Arendt has argued, private and unworldly?66

Perhaps a better conception of love for Bańkowski's argument is to consider friendship love, philia. Bańkowski actually mentions friendship when he uses the example of the guest and host relationship (friendship) to illustrate the relationship between law and love, but he does not discuss it in any detail.

Friendship love has long featured in the history of the idea of love. Aristotle says there are three kinds of love that emerge from three types

64 There are some strong critiques of romantic love. The feminist critique centers around the idea that through love women become locked into patriarchy, family, motherhood and domesticity. For example, see Wendy Langford, Revolutions of the Heart: Gender, Power and the Delusions of Love (Routledge, 1999) and Mary Evans, Love an Unromantic Discussion (Polity, 2002). Queer critique has also argued against romantic love on the ground that it is heteronormative. For example, see Cheshire Calhoun, Feminism, the Family, and the Politics of the Closet: Lesbian and Gay Displacement, (Oxford University Press, 2000); Cheshire Calhoun, 'Sexuality Injustice' (1995) 9 Notre Dame Journal of Law Ethics \& Public Policy 241; Cheshire Calhoun, 'Making Up Emotional People the Case of Romantic Love' in Susan A Bandes (ed), The Passions of Law (NYU Press, 2001) 217-240; and Cheshire Calhoun, 'Family's Outlaws: Rethinking the Connections Between Feminism, Lesbianism and the Family' in Hilde Lindermann Nelson (ed), Feminism and Families (Routledge, 1997) 131-150.

65 Gaita, above n 63, 27.

66 Shin Chiba, 'Hannah Arendt on Love and the Political: Love, Friendship and Citizenship' (1995) 57 The Review of Politics 506. 
of friendship. ${ }^{67}$ First there is friendship based on utility. Friends in this type of relationship do not care about each other as separate individuals; they are self-interested and only love each other for what benefit they can get out of each other. The second type of friendship is based on pleasure and is similar to the friendship based on utility. Here friends love each other only according to the pleasure they can get from each other. The third type of friendship is based on the love for goodness. Here friends love each other for what they are and not what they can get from each other. This is true, or perfect friendship, and only people who are morally virtuous can enter into this type of relationship. Only good people 'can love each other's character as opposed to incidental benefits of pleasure and utility'. ${ }^{68}$

For Aristotle, friendship love goes beyond a relationship between two people. Friendship love is the model of society. It is linked to civic harmony and civic duty and to morality and justice. Friendship is the model for love, and justice is the model for friendship. A moral community needs both justice and friendship. The type of friendship that provides this model for love and justice is that which is based upon a sense of being good, and doing good. This type of friendship constitutes the model for justice, good men recognising each other's goodness and loving each other for it. A friend does good, and wishes good for another, for their own sake. As Singer states, 'for Aristotle this constitutes the truest form of justice. Both parties being alike in excellence, each warrants similar good, and as friends each will be happy to give the other his due'. ${ }^{69}$

Cicero in De Amicitia ${ }^{70}$ said that there is nothing greater in the world than friendship. Life is not worth living without the goodwill of a friend. This is not just for utilitarian reasons but because it is a genuine and spontaneous springing not from need but from nature from an inclination of the soul joined with a feeling of love'. ${ }^{71}$ True friendship however, can only exist between good people. A good person is honourable, just, generous, courageous, loyal, and free from greed, intemperance and violence. There are also other limits, it can end when differences between people emerge, and it must never trump duty and loyalty to your country. Friendship love therefore does not override all other duties. As Cicero said, a friend must 'neither ask dishonourable things, nor do them, if asked', ${ }^{72}$ and as May says, you can love a murderer but you can't be friends with one. ${ }^{73}$

However we must not mistake friendship's regard for ethics and rules, for social conventions and conservatism. Like romantic love, friendship love ignores boundaries created by class, religion, race, ethnicity, sex,

67 Aristotle, The Nicomachean Ethics (H Rackman trans, Harvard University Press, 1982) 457-471.

68 Singer, above n 26, 89.

69 Ibid, 95.

70 Marcus Tullius Cicero, Cicero's Offices: Essays and Select Letters (Dent, 1920).

71 AC Grayling, Friendship (Vices and Virtues) (Yale University Press, 2013) 48.

72 Cicero de Amicitia quoted in ibid, 49.

73 May, above n 15, 67. 
gender, sexuality, politics and others, and embodies all of the same modern and egalitarian values. As Blatterer argues, friendship is embedded in all of the watchwords of liberal democracies, '[f]reedom of association, autonomy, equality, trust, respect, justice ... Friendship embodies the public norms and ideals we associate with politically, economically, and socially mature societies'. ${ }^{74}$

Friendship love as philosophised by Aristotle gives a sense of the other, her needs and welfare, and while like eros it is exclusive and preferential, as discussed above, Aristotle attributed to it the ability to form a model for a just community. In other words the values of friendship can be translated into a general concern for others. Grayling argues that it is not too much of a stretch to see the actions of activists working on human rights and social justice campaigns, and those working in charitable organisations as acting out of friendship to humanity. And there is also no reason why animal rights campaigners cannot be seen as friends to animals, and environmental campaigners as friends to the environment. He says:

this is not to stretch the term one whit, because what is implicated in the general idea of being a friend to $\mathrm{X}$, whoever or whatever $\mathrm{X}$ is, is the set of more particular ideas about concern, sympathy, interest, action towards the welfare of, and preparedness to sacrifice something of one's own substance or convenience for, that person or object. ${ }^{75}$

In these ways, friendship love has been seen as embodying civic and political potential. For example, Blatterer has argued that we can only understand decency by experiencing it, and the place we mostly experience it is in friendship. ${ }^{76}$ Arendt saw friendship and the discourse of friends as uniting people as citizens and creating a sense of what is human. She said, '[w]e humanize what is going on in the world and in ourselves only by speaking of it [with our friends], and in the course of speaking of it we learn to be human'. ${ }^{77}$ In fact, Chiba has argued that Hannah Arendt's amour mundi, a generalised 'humanized love of humanity' can be largely understood as being rooted in Aristotle and Cicero's upholding of the public and political capacity of friendship. ${ }^{78}$

The connection of friendship with the political, with ideas of decency and justice argued above, moves friendship love into the public sphere. We cannot deny that friendship also exists as a private relationship between two people, however as Chiba argues 'friendship presents itself as a closest resemblance or image to the public activity of citizens, characteristics of which can consist in spontaneity, discussion, speech, common deliberation, persuasion, cooperation, or the absence of hierarchy'. ${ }^{79}$

$74 \quad$ Harry Blatterer, Everyday Friendships: Intimacy as Freedom in a Complex World (Palgrave, 2014) 5.

75 Grayling, above $\mathrm{n} 71,189$.

76 Blatterer, above n 74, 191.

77 Hannah Arendt quoted in Shin Chiba, 'Hannah Arendt on Love and the Political: Love, Friendship and Citizenship' (1995) 57 The Review of Politics 522.

78 Chiba, above n 66.

79 Ibid, 519. 
From the above discussion we can essentialise the features of friendship love as a means of recognising goodness in others and doing good for others. While it is preferential and discriminatory, it is also rooted in a more general idea of goodness and ethics, and is consequently subject to rules. Furthermore, since Aristotle, it has always been connected to social and political goals therefore making the ideals within it fit for both the private realm and the public discourse. All of these features make it a good fit with law.

\section{Conclusion}

Zenon Bańkowski has argued that law and love are connected and need one another. Love is essential to make law respond to individual circumstances and meet individual needs. It functions to reduce the rigidity of rules (legalism), and to motivate social acts that are not necessarily required or facilitated by rules, but are nonetheless necessary for society. The features that enable love to fulfil these functions are that love is spontaneous, irrational and individual. It is linked to autonomy rather than heteronomy, and it creates a feeling of what is 'right'.

This argument leads one to ask what he means when he talks of love. Bańkowski's argument concerning the connection of love and law, and the function he attributes to love in law, relies on ideas that cross the traditions of thinking about love that I have delineated my discussion with. He uses the classical idea that love is a means by which we connect to, and attain goodness. The Christian love of God, and through him others, is also a clear reference point for Bańkowski. Furthermore, romantic love's radical ruptures of existing social barriers and its aggressive advocacy for individual agency is unmistakable in his argument. The appropriateness of these traditions of love for law are, however, questionable. Classical love's concept of merger, and its connection with love as an avenue to solve our inadequacies are hard to translate into modern society. Similarly, Christianity in the end can only fully make sense for Christians. And, romantic love's exclusivity and preferentialism, its connection with sexual love, and its largely private nature, make it a difficult discourse for law.

If law and love are to be seen as inter-connected and necessary to each other I have argued that a better model of love may be friendship love. Unlike the other forms of love, friendship love is both private and public. It is a relationship between individuals, but it has also long been associated with values that are desirable in the public sphere. As a public concept philosophers have associated it directly with politics, but the same values are equally applicable and valuable in law. Furthermore, while friendship love is exclusive and preferential, it is not as exclusive and preferential as romantic love. Despite the current preoccupation with the authenticity of having a large number of Facebook friends, it is the case that one interpretation of having many friends is that it constitutes a sign of a good character. Another feature of friendship love which makes it more compatible with law is that it has always been associated with 
rules and ethics. It relies on all parties being good and behaving well for it to continue, and as we saw above, it is always connected to living a lawful life. This is in contrast to contemporary romantic love where the rules are always negotiable and determined by the parties themselves. Friendship love is considered a more ethical love and yet still is part of the modern egalitarian tradition that values freedom and equality. Finally, friendship love has the potential to create a model of goodwill for others without any reference to religion, faith and belief. As such it is more relevant to law in a modern, secular society than Christian love can be for our times. 